\title{
O FUTURO DA ENGENHARIA OU A ENGENHARIA DO FUTURO !
}

\author{
Eng ${ }^{\circ}$. Mario Arthur de Souza Fontes
}

\section{Ensaio}

Na mitologia Grega há um deus chamado JANUS, que tem um olho só na frente da testa, para ver o futuro e um olho atrás da cabeça, para ver o passado.

Se estiver vivo..., mas com certeza deve ainda estar..., porque os deuses não morrem jamais..., assim diz a máxima; e se olhasse a nossa engenharia iria ver com certeza, muitas coisas interessantes, senão vejamos:

"vislumbraria com o seu olho de ver o passado e veria uma Engenharia pujante, com grande força tecnológica, construindo a base da infra-estrutura de um País preparado para despontar no”hancking”das grandes Nações do Século XX; JANUS, veria também essa Engenharia, construindo e participando da modernização da superestrutura dessa Nação líder do Continente Sul; veria ainda hoje, a maior hidrelétrica em operação, a usina de geração Itaipú e todo um programa de eletrificação e de domínio do maiores rios que este mundo já postou a olhar; enxergaria o maior programa rodoviário, jamais construído...???, é certo, ficando somente no papel; veria os metrôs de São Paulo e do Rio de Janeiro e tantas e tantas outras obras de envergadura, dessa infra-estrutura; iria ver programas como o Proálcool, o domínio da tecnologia agrícola na vastidão do solo do nosso Centro-Oeste e outros...”.

E, o que veria o olho postado na frente da testa de JANUS?

"veria em visão máxima de futuro, para este País de dimensões continentais, com certeza, muito pouco de Engenharia e muito de macroeconomia e diga-se de passagem, de péssima qualidade macroeconômica e etc..., etc..., e etc...”.

Na verdade, perdemos o rumo e isso já faz vinte e tantos anos... . Teremos que aprender tudo novamente; aprender a fazer o desenvolvimento econômico, o que não será fácil e nem tão rápido; selecionar empreendedores de caráter ilibado; preparar mão de obra especializada; implementar o entendimento que o maior capital é o trabalho e isso para todos; aumentar a auto-estima dos profissionais brasileiros e sensibilizar o governo federal, para esse grande momento. Mas acreditamos, que uma longa caminhada, começa sempre com um primeiro passo e neste primeiro e importantíssimo passo, somente a Universidade pode ajudar. Porque a Universidade é hoje um lócus onde à luz das idéias, traz a discussão dos aspectos gerais e dos multisetoriais da Engenharia e do desenvolvimento, porque aí está o seu vocacional, pois a Universidade é a grande formadora. Ninguém conseguirá preparar esse futuro sozinho, será necessária a ajuda de todos e esperamos que estes sejam muitos...; só assim as coisas poderão acontecer e mudar com certeza.

Aí então, o Brasil do futuro se confundirá com a Engenharia do futuro..., e JANUS não ficará obrigado por sua visão de futuro, a ver as coisas se apresentarem ainda hoje, sem nenhuma ou quase nenhuma perspectiva em curto prazo.

Todos deveremos acreditar, ter certeza e muita fé neste futuro o que para isso, somente teremos que encará-lo.

\section{Informações bibliográficas:}

Conforme a NBR 6023:2002 da Associação Brasileira de Normas Técnicas (ABNT), este texto científico publicado em periódico eletrônico deve ser citado da seguinte forma: FONTES, M. A. S. . O Futuro Da Engenharia Ou A Engenharia Do Futuro ! Cadernos UniFOA, Volta Redonda, ano 1, nº. 1, jul. 2006. Disponível em: $<$ http://www.unifoa.edu.br/pesquisa/caderno/edicao/01/11.pdf > 